\title{
ЕТНИЧКА СТРУКТУРА СТАНОВНИШТВА У НАСЕЉИМА ТЕМИШВАРСКЕ ЕПАРХИЈЕ СРЕДИНОМ ХVIII ВЕКА
}

САЖЕТАК: У раду се даје приказ етничке структуре насеља на простору Темишварске епархије према подацима државних пописа Темишварског Баната из 1743, 1753. и 1774. године. Први и последњи попис су целовити, док попису из 1753. године недостају подаци за Липовски и Лугошки дистрикт. Анализом поменутих докумената могу се у потпуности сагледати етнички односи на територији епархије, у чијим су западним деловима већину чинили Срби, а у источним деловима Румуни. Може се пратити и њихов развој, с јасном тенденцијом усложњавања у другој половини XVIII столећа.

КљУЧНЕ РЕЧИ: Карловачка митрополија, Темишварска епархија, Хабзбуршка монархија, Темишварски Банат, историјска демографија, етничка структура, Срби, Румуни, Немци, XVIII век

Током XVIII столећа Темишварска епархија обухватала је простор од Дунава на југозападу, Мориша на северу, доњег тока реке Тисе на западу и копнене границе према Вршачкој епархији на истоку, дакле, већи део Баната. ${ }^{1}$

У зависности од административних померања на простору Темишварског Баната током XVIII века мењале су се и границе банатских епархија, Темишварске и Вршачке. Промене никада нису биле већег обима јер се радило,

${ }^{1}$ Граница између Темишварске и Вршачке епархије полазила је од Ковина на Дунаву, ишла дуж граница дистриката ка североистоку и избијала узводно од Липове на реку Мориш. Детаљније о Темишварској епархији, од новијих радова, видети: Љ. И. Пузовић, „Границе, насеља и парохије Темишварске епархије (1716-1779): прилог проучавању историје православља у Банату”, Зборник Майиие срйске за исйорију 96 (2017), 35-52; Иста, „Парохијско свештенство Темишварске епархије средином XVIII века", Темищварски зборник 9 (2017), 19-39; Иста, „Парохијски храмови у Темишварској епархији средином XVIII века”, Темищварски зборник 10 (2018), 29-41; Иста, „Темишварска епархија од Пожаревачког мира до Темишварског сабора (1718-1790)", Међународни научни скуп Осам векова ауйокефалије Срйске йравославне иркве 1219-2019: исйоријско, богоословско и кулйурно наслеђе, Православни богословски факултет, 10-14. децембар 2018. године (у штампи). 
углавном, о питању припадности неколико села једној или другој епархији. Изузетак су чинила насеља Лугошко-фачетског дистрикта, који је почетком столећа већински припадао Темишварској епархији, да би јој током седамдесетих година био у потпуности прикључен.

Након протеривања турских трупа са простора Баната (1717) десиле су се значајне промене на пољу етничких односа на територији ове епархије. Непосредно после Пожаревачког мира (1718) становништво су чинили само Срби и Румуни. Срби су већински насељавали равничарске дистрикте - Бечкеречки, Панчевачки и Чанадски, а Румуни су били једино становништво планинског, Лугошко-фачетског дистрикта. Темишварски, Чаковски и Липовски дистрикти били су са мешовитим становништвом. ${ }^{2}$

Према државним пописима насеља Темишварског Баната из 1743, ${ }^{3} 1753.4$ и 1774. ${ }^{5}$ године могуће је реконструисати етничку слику Темишварске епархије, као и промене које су се дешавале на том пољу. Пописи из 1743. и 1774. године су потпуни, то јест односе се на сва насеља Темишварског Баната, док попису из 1753. године недостају подаци за Липовски и Лугошко-фачетски дистрикт. Сви су извршени према административној подели Баната на дистрикте. За проучавање етничке структуре насеља једне црквене јединице, у овом случају Темишварске епархије, могу да се користе пописи државних власти који садрже релевантне податке јер се тачно зна који су дистрикти припадали Темишварској, а који Вршачкој епархији. Помоћу црквених пописа из овог столећа поуздано се може утврдити и епархијска припадност села̂ Лугошко-фачетског дистрикта, у времену када је територија дистрикта била јурисдикционо подељена између поменутих епархија. 6

У епархији је 1743. године било 307 насеља. Од тога броја 89 било је чисто српских (29\%), 185 румунских (60,26 \%), 14 немачких (4,56 \%), два бугарска $(0,65 \%)$ и једно италијанско $(0,33 \%)$. Насеља са мешовитим становништвом било је $15(4,89 \%)$ и то 12 српско-румунских (3,91\%) и три српско-немачка $(0,98 \%)$. Без ближе етничке ознаке било је једно насеље $(0,33 \%){ }^{7}$

Према попису из 1774. године било је 382 насеља. Од тог броја 71 је било чисто српско (18,58 \%), 212 румунских $(55,21 \%), 43$ немачка $(11,2 \%)$ и једно мађарско насеље $(0,26 \%)$. Од насеља са мешовитим становништвом највише је било српско-румунских - $38(9,89 \%)$ и румунско-српских - $6(1,56 \%)$. Немачко-српска била су два места $(0,52 \%)$, немачко-румунска три $(0,78 \%)$

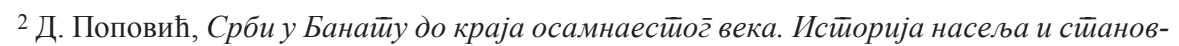
нимйва, Београд 1955, 50.

3 Д. Поповић, Срби у Банаӣу до краја осамнаесииог̄ века, 81; J. Wolf, Quellen zur Wirtschafts-, Sozial- und Verwaltungsgeschichte des Banats im 18. Jahrhundert, Materialien. Heft 5, Tübingen 1995, 252-295.

4 Д. Поповић, Срби у Банайу до краја осамнаест̄ог̄ века, 81; Д. Поповић, Ж. Сечански, Грађа за истиорију насеља у Војводини од 1695 до 1796, Нови Сад 1936, 67-71.

5 J. Wolf, Quellen zur Wirtschafts-, Sozial- und Verwaltungsgeschichte des Banats im 18. Jahrhundert, 296-322; J. J. Ерлер, Банай, Панчево 2003, 78-94.

6 Д. Руварац, Ойис Темищварске ейархије 1727. гоодине, Сремски Карловци 1923, 7-10; АСАНУК, МП, „А”, 1733/102; Д. Руварац, „Темишварска епархија 1764”, Срйски Сион 15 (1905), 466-467; АСАНУК, МП, „Б”, 1767/45; АСАНУК, МП, „Б”, 1771/41; Д. Руварац, Срйска мийройолија карловачка око йоловине XVIII века, Сремски Карловци 1902, 101-112, 147-152.

7 Д. Поповић, Срби у Банайу до краја осамнаесйог̄ века, 81; J. Wolf, Quellen zur Wirtschafts-, Sozial- und Verwaltungsgeschichte des Banats im 18. Jahrhundert, 252-295.
} 
и једно српско-мађарско (0,26 \%). Српско-румунско-немачких насеља било је пет $(1,30 \%) .8$

\section{3. година}

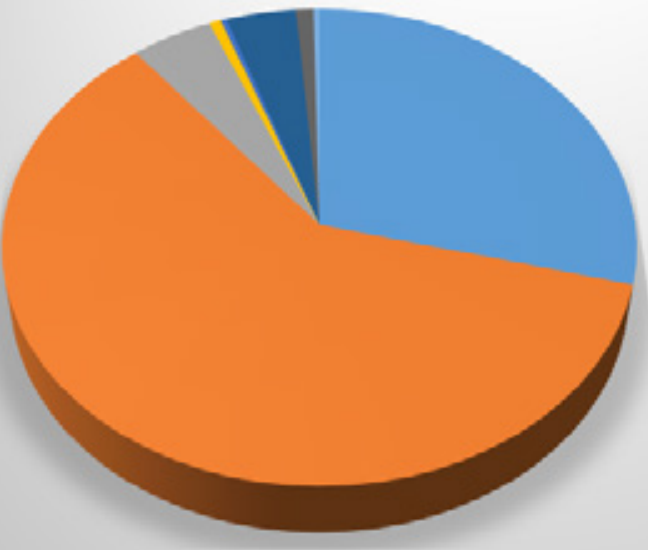

- Српска насеља

пумунска насеља

- Немачка насеља

- Бугарска насель

- Италијанска насеља

ш Српско-румунска насеља

- Немачко-српска насеља

- Без ознаке

Графикон 1. Насеља Темишварске епархије према попису из 1743. године

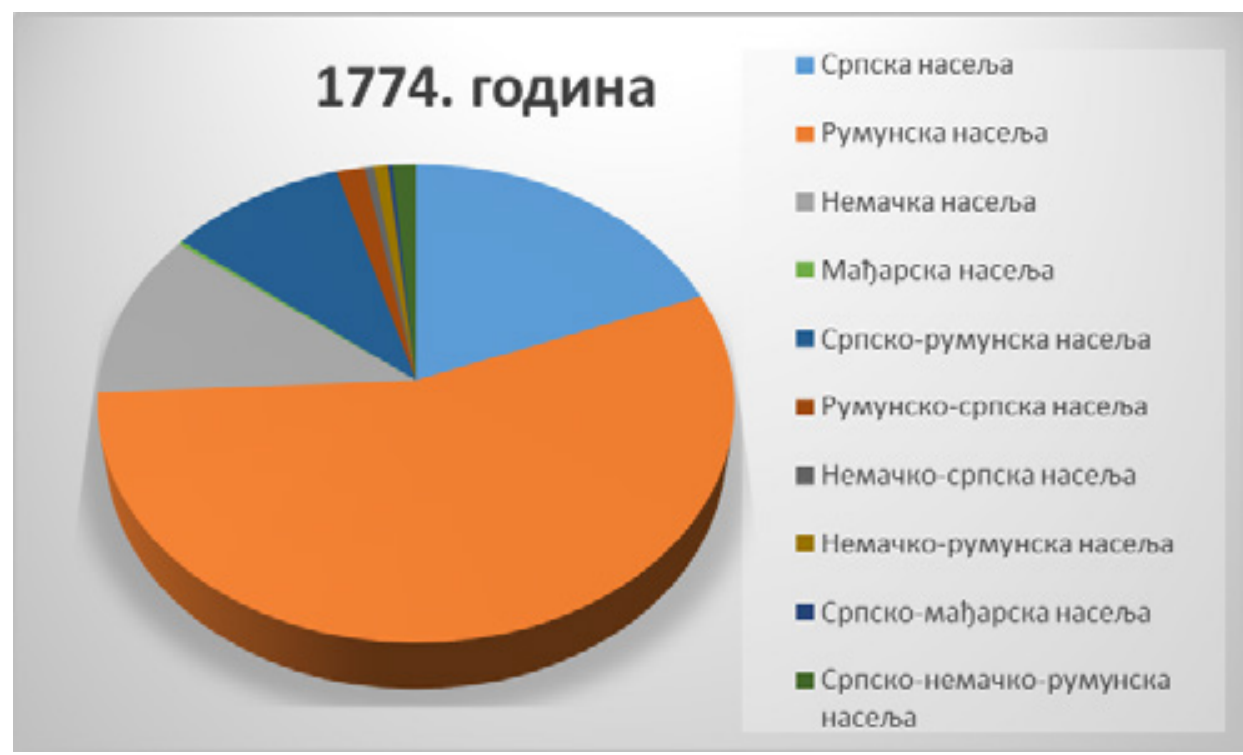

Графикон 2. Насеља Темишварске епархије према попису из 1774. године

8 J. Wolf, Quellen zur Wirtschafts-, Sozial- und Verwaltungsgeschichte des Banats im 18. Jahrhundert, 296-322; J. J. Ерлер, Банат̄, 78-94. 
Етнички најшароликији био је Темишварски дистрикт, у којем је поред српских и румунских насеља било и бугарских, италијанских и немачких места, као и мешовитих српско-румунских, немачко-српских, румунско-српских, немачко-румунских и српско-немачко-румунских насеобина.

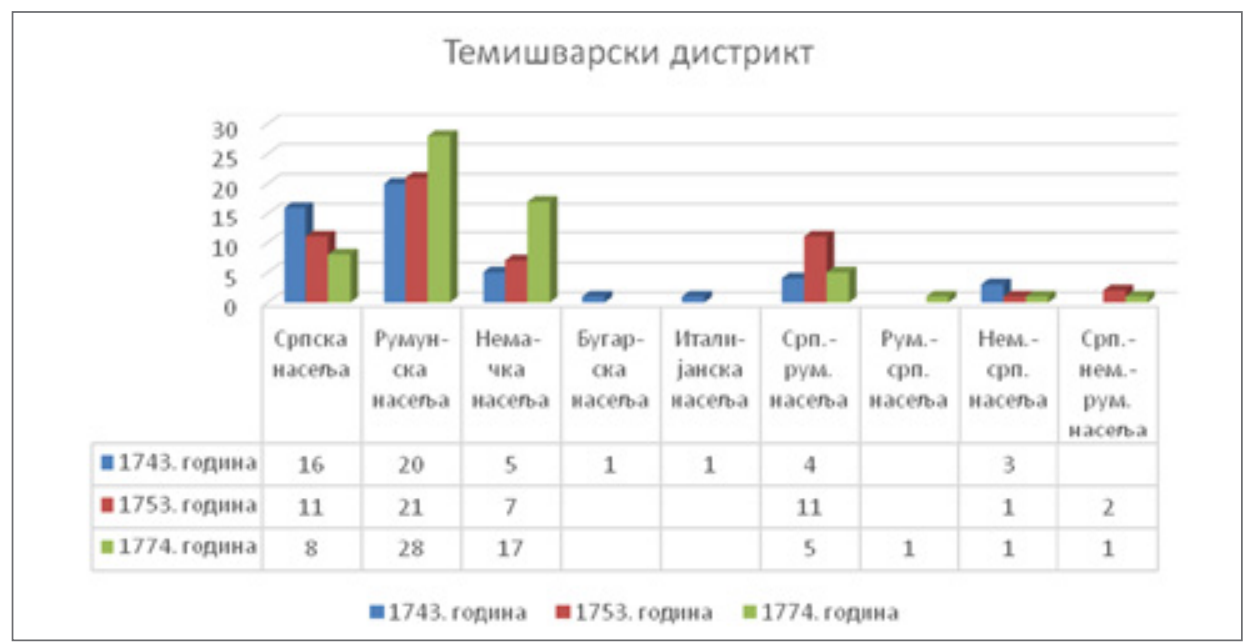

Графикон 3. Насеља Темишварског дистрикта према етничкој структури

Са већинским српским живљем, током целог XVIII столећа, били су Бечкеречки, Панчевачки и Чанадски дистрикт.

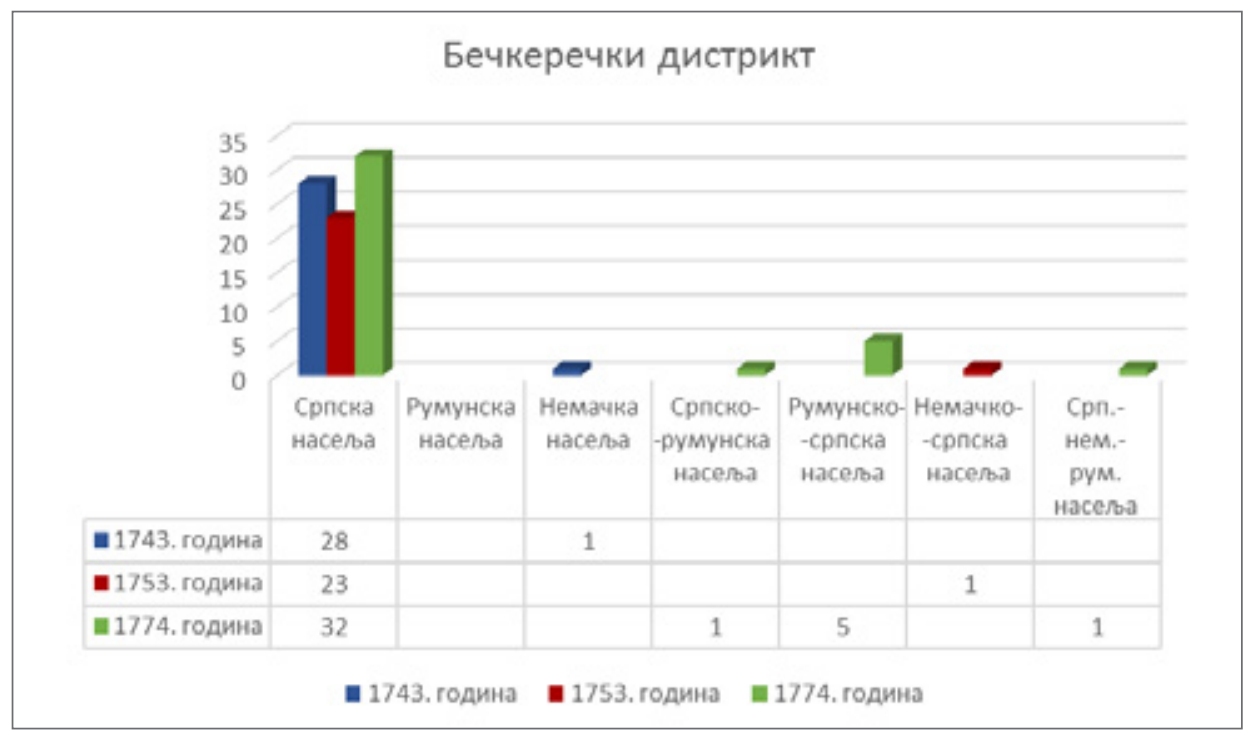

Графикон 4. Насеља Бечкеречког дистрикта према етничкој структури 


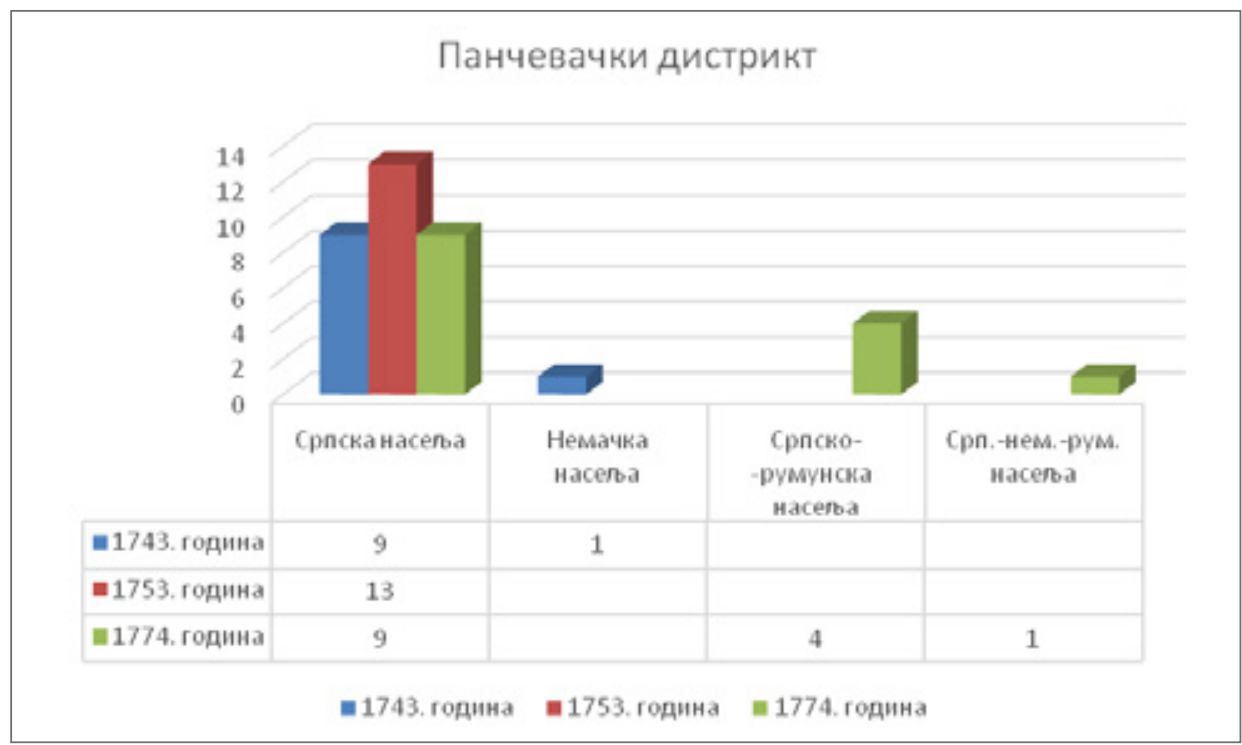

Графикон 5. Насеља Панчевачког дистрикта према етничкој структури

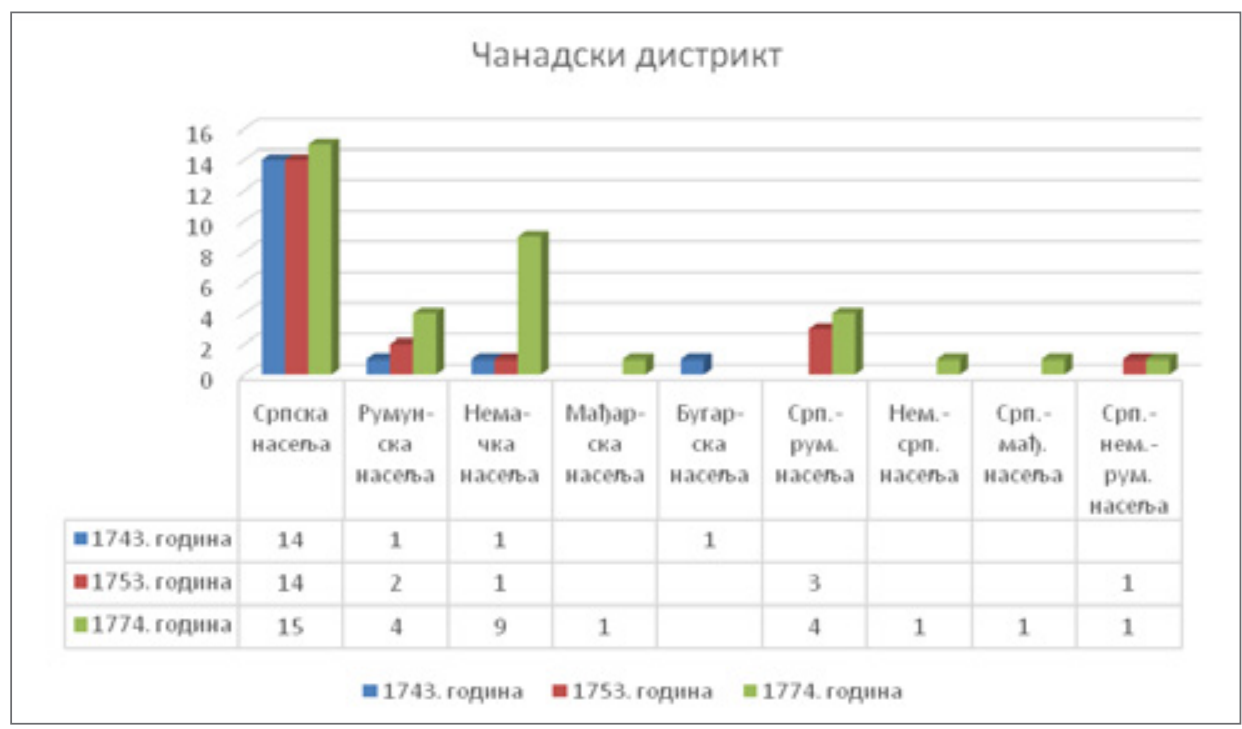

Графикон 6. Насеља Чанадског дистрикта према етничкој структури

Већински румунско становништво живело је у Чаковском, Липовском и Лугошко-фачетском дистрикту. Румуни су се од почетка столећа постепено спуштали са Карпата у равничарски Банат и тако појачавали свој етнички елеменат. О њиховој појави у Банату нема тачних података јер нису имали сталних станишта будући да су, углавном, живели као полуномади. Током 
аустро-турског рата (1737-1739) мноштво Румуна је избегло у Ердељ и Банат. По закључењу Београдског мира (1739) и припајању Мале Влашке Турској настављена је тенденција усељавања Румуна у Темишварски Банат. 9 Њихова колонизација трајала је и за време владавине Марије Терезије (1740-1780). Како би спречила ову појаву, наредбом од 11. септембра 1765. године забранила је њихово даље усељавање. Оваква наредба донета је да се не би реметио план по којем је требало да Немци буду бројно надмоћнији од Срба и Румуна у Банату, као и због честих напада румунских пљачкаша на Немце. ${ }^{10}$ Насељавање Румуна на граници са Турском такође је могло да буде ризичан потез због њиховог евентуалног савезништва са Турцима, чега се царица прибојавала. Стога је 1770. године наредила да се српским и румунским емигрантима не дозволи насељавање у Бечкеречком дистрикту, већ да се упуте у Чанадски, Липовски, Темишварски и Лугошко-фачетски дистрикт, подаље од границе. ${ }^{11}$

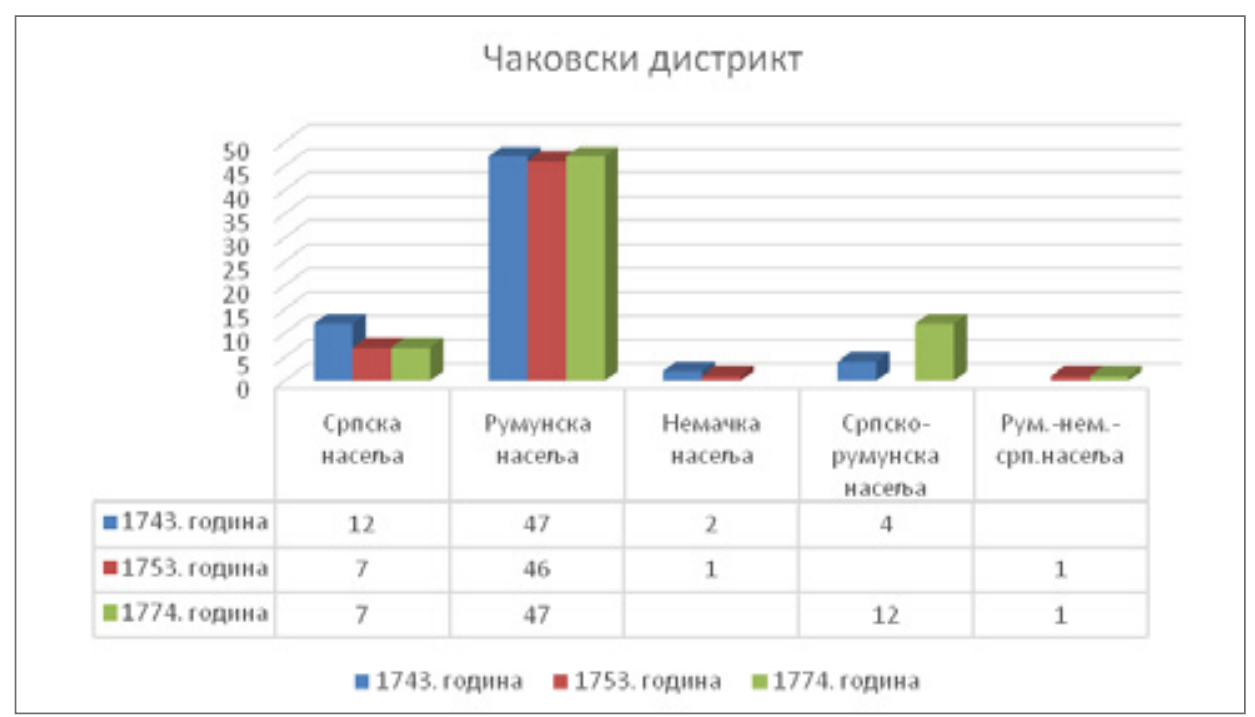

Графикон 7. Насеља Чаковског дистрикта према етничкој структури

9 Д. Руварац, „Страдање архимандрита Андреја Атанасијевића и неколико његових писама”, Архив за истиорију Срйске йравославне Карловачке миіиройолије 1 (1911), 85.

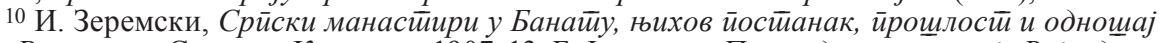
ирема Румунима, Сремски Карловци 1907, 13; Б. Јанкулов, Прегллед колонизације Војводине y 18. и 19. веку, Нови Сад 1961, 52-56. У рату 1737-1739. године Румуни су се приклонили Турцима и заједно са њима пљачкали по Банату. Царица их је и поред тога штитила, сматрајући да би уз боље васпитање могли да буду од велике користи за државу. Стога је настојала да што више Немаца насели у источни Банат међу Румуне, како би немачка насеља била нека врста радне школе за тамошње Румуне. Међутим, представници Земаљске администрације у Темишвару били су другачијег мишљења, поучени искуством из претходног рата, те су покушавали да плански раселе Румуне из источног по целом Банату. Расељавање је спровођено уз велике напоре, а крајњи циљ је био да се одвикну од номадског и пљачкашког начина живота и привикну на земљорадњу.

${ }^{11}$ Б. Јанкулов, Прегллед колонизаиије Војводине, 52-56. 


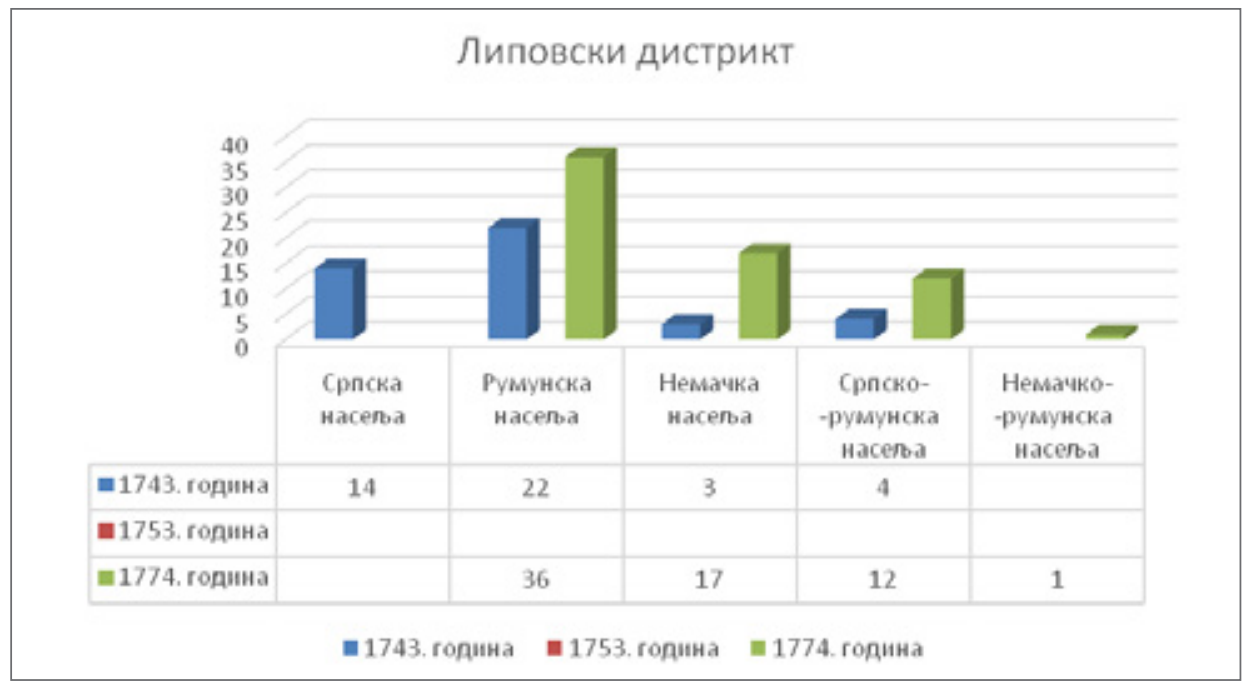

Графикон 8. Насеља Липовског дистрикта према етничкој структури

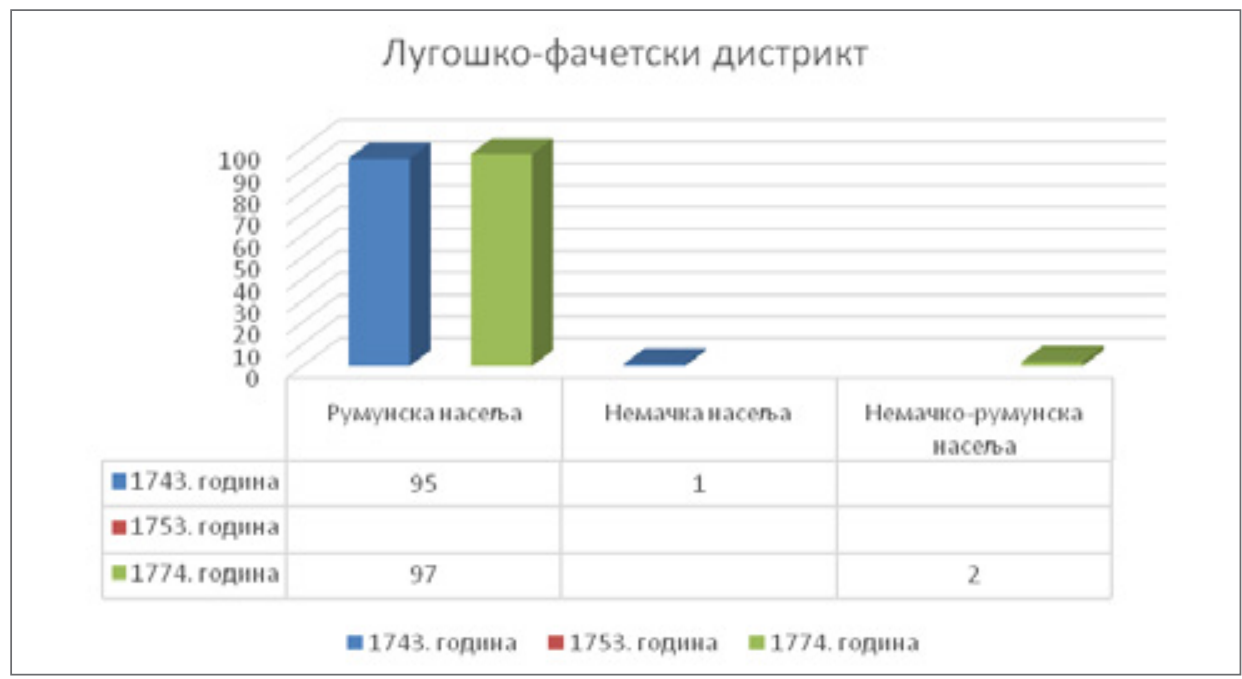

Графикон 9. Насеља Лугошко-фачетског дистрикта према етничкој структури

Имајући на уму претходно изложена демографска кретања, може се видети да је средином XVIII века дошло до великих етничких промена. За само тридесет година број чисто српских насеља смањио се за 18, а чисто румунских повећао за 27, што је, једним делом, последица укључивања целокупног Лугошко-фачетског дистрикта у Темишварску епархију. Следствено томе, повећао се и број насеља са мешовитим становништвом, највише српско-румунских, чак за 29. До највећих етничких промена дошло је на подручју Липовског дистрикта, у периоду од 1743. до 1774. године. У овом 
дистрикту 1743. године било је 14 српских, 22 румунска, три немачка и четири српско-румунска села. Тридесет година касније у дистрикту није било ниједно српско село, 12 је било српско-румунских, док је било чак 36 румунских и 17 немачких села. ${ }^{12}$

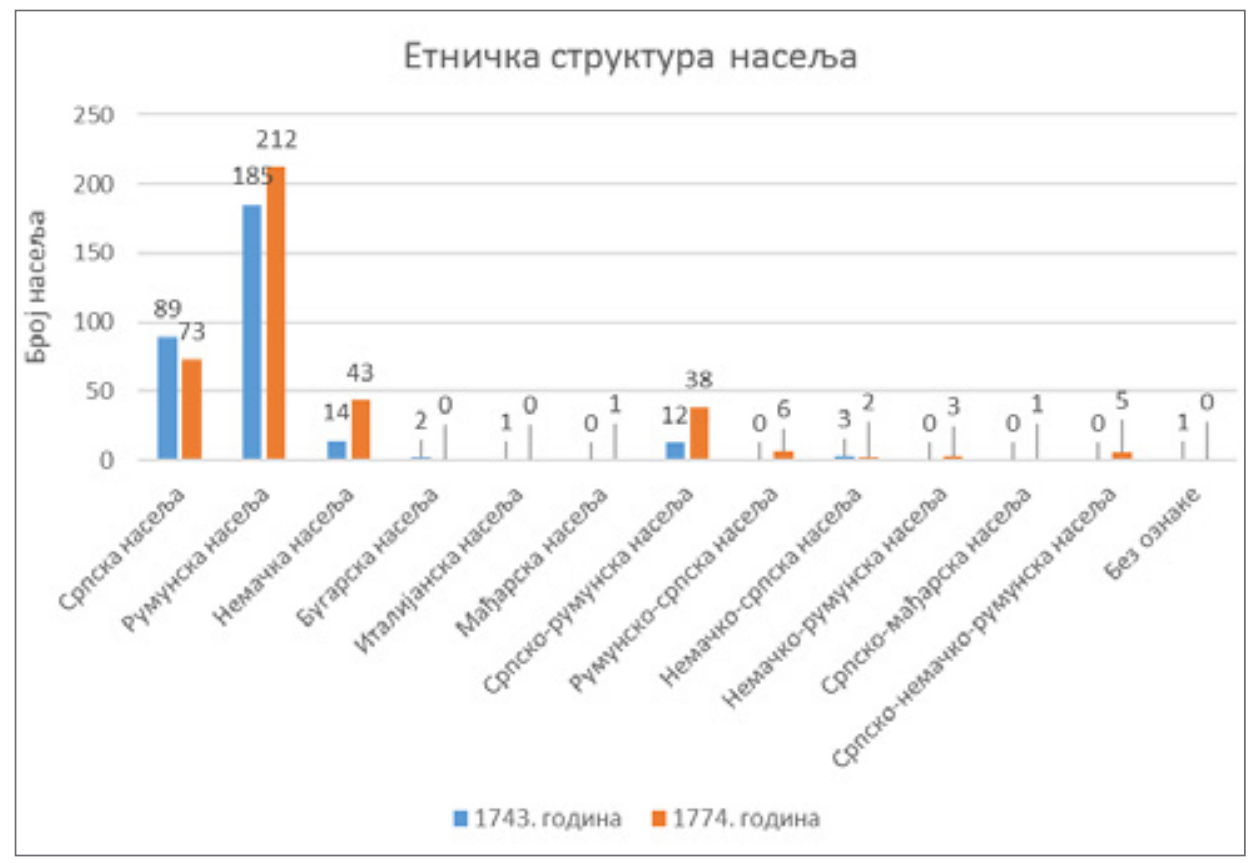

Графикон 10. Етничка слика насеља Темишварске епархије према пописима из 1743. и 1774. године

Поред Срба и Румуна, важан чинилац на простору Баната временом су постали и Немци, чијих насеља овде није било до тридесетих година XVIII века. Њихова насеља су 1743. године чинила само 4,56 \% укупног броја, док је тај постотак 1753. године био скоро три пута већи - $11,2 \%$, не рачунајући мешовита насеља. ${ }^{13}$ Систематска колонизација Баната почела је одмах после Пожаревачког мира. Стратегијски разлог налагао је да Немци што пре направе једну врсту зоне раздвајања између савезника, Турака и Мађара, стварајући на тај начин и привредну подлогу за вођење даљих ратова против Турске. Прва група Немаца приспела је у Панчево 1718. године. Насељеници су били из Тирола, Крањске, Чешке, Шлезије, горњег Дунава и средње Рајне. Већином су били рудари и занатлије, а у мањој мери земљорадници. Велики број, углавном Шваба, досељен је 1723/24. године. Насељени су у 17 банатских места, углавном у источном Банату, али и у Бечкерек и Панчево.

12 Д. Поповић, Срби у Банайу, 81; Д. Поповић, Ж. Сечански, Грађа за исйорију насељь у Војводини, 67-71; Ј. Ј. Ерлер, Банат̄, 78-94.

13 J. Wolf, Quellen zur Wirtschafts-, Sozial- und Verwaltungsgeschichte des Banats im 18. Jahrhundert, 252-295. 
Међутим, тешко су успевали да се аклиматизују у новој средини, па је због превелике смртности новонастањених у Немачкој кружило мишљење о Банату као о „гробници Немаца”. ${ }^{4}$

Привилегован положај досељеника, нарочито ослобађање од плаћања пореза и уконачивања војске, забрињавао је староседеоце. Плашили су се већих намета у новонасталој ситуацији, као и снажнијег притиска уније јер су промене етничких прилика праћене променом верске структуре. На територију на којој су вековима уназад живели углавном православни Срби и Румуни, од хришћанског становништва, досељавани су привилеговани народи римокатоличке вере, због чега су многи староседеоци пребегли у Србију, Влашку, па чак и у Турску. Због тога је број становника у неким местима преполовљен, док су поједина насеља, попут чисто српских села Сечња и Модоша, потпуно опустела. 15

Аустро-турски рат (1737-1739) ставио је на пробу способност немачких колониста. После успешног почетка аустријска војска почела је да трпи поразе. Турци су продрли у Банат где им се придружио део Румуна, који су заједно са њима пустошили његов јужни део. Ратне операције и болести, нарочито кугу, колонисти и њихова насеља нису преживели, чиме је неуспешно окончан процес колонизације цара Карла VI (1711-1740) и грофа Мерсија. ${ }^{16}$

За време владавине Марије Терезије (1740-1780) наставило се са колонизацијом. Оснивање Немачко-банатске регименте 1764. године дало је велики замах овом процесу. Темељније планирана и припремана од претходних, ова колонизација подразумевала је насељавање ветерана из ветеранских домова и стајаћих регименти из целе Хабзбуршке монархије, различитог етничког порекла. ${ }^{17}$ Истовремено, колонисти су насељавани широм Баната и изван Војне границе, што је умногоме утицало на промену етничке слике насеља Темишварске епархије. Цар Јосиф II (1780-1790), син и наследник Марије Терезије, који је Банат посетио у два наврата, 1767. и 1773. године, радио је на побољшању колонизационе политике с циљем трајног ојачавања немачког елемента на овом простору. ${ }^{18}$

У варошима, посебно седиштима дистриката, поред поменутих народа живели су и Грци, Цинцари и Јевреји, који су се већином бавили трговином. Убрзо по ослобођењу Баната гроф Мерси населио је у околини Бечкерека око 200 Јермена, углавном искусних трговаца. ${ }^{19}$ У Темишвару је 1739. године

14 Б. Јанкулов, Прег̄лед колонизачије Војводине, 7-8.

15 У Банат нису слати протестанти јер је постојала бојазан да би се они у случају рата, као и Мађари, могли придружити Турцима. Због тога су колонизовани само римокатолици јер се веровало да су они носиоци германизације и једини чврст бедем пред фанатичношћу Турака. Уп. Б. Јанкулов, Прег̄лед колонизаиије Војводине, 7-16.

${ }^{16}$ Гроф Клаудије Флоримунд Мерси (Claudius F. Mercy), председник Земаљске администрације у Темишвару (1718-1734). Уп. Б. Јанкулов, Прег̈лед колонизачије Војводине, 11-12; J. Илић Мандић, „Планско насељавање у Војној крајини: колонисти-ветерани у Немачко-банатској регименти (1764-1788)", Држава и йолийике уйрављања (18-20. век), Београд 2017, 37-38.

17 Детаљно о овој колонизацији: Ј. Илић Мандић, „Планско насељавање у Војној крајини: колонисти-ветерани у Немачко-банатској регименти (1764-1788)”, 37-56.

18 Б. Јанкулов, Прегллед колонизаиије Војводине, 2. Више о колонизацији Немаца од 1762. године видети у: E. Schimscha, Technik und Methoden der Theresianischen Besiedlung des Banats, Wien 1939.

${ }^{19}$ Б. Јанкулов, Прег̄лед колонизаиије Војводине, 64. 
било 6 грчких и 14 цинцарских трговачко-занатлијских породица, али је вероватно да се њихов број временом повећавао. ${ }^{20}$

Након освајања Баната нове власти су у овој области затекле и Сефарде или „турске Јевреје”, како су их називали. У Темишвару је њихова општина бројала 144 члана. Дозвољено им је да остану у насељу, али под надзором, у посебној четврти унутар тврђаве. Упркос свему, Темишвар је био привлачан за Јевреје због великих могућности за уносно пословање, па су у њега пристигли и Ашкенази из унутрашњости Хабзбушке монархије. Због тога је темишварска администрација одлучила да њихов број ограничи на 60 кућа. Мере за ограничавање досељавања нису биле делотворне, те су крајем деведесетих година XVIII века евидентиране 84 јеврејске породице у Темишвару. ${ }^{21}$

Банат су насељавали и Роми, који су овде дошли са Турцима. Царица Марија Терезија започела је планско спровођење њиховог прилагођавања староседелачком начину живота. План је предвиђао укидање имена Циганин и увођење назива Hojбауер (Neubauer) - Новоселаu. Следећи корак требало је да буде привикавање на седелачки начин живота и бављење земљорадњом. Међутим, присилне мере за спровођење планова нису успеле, као ни покушај да их натерају да похађају школу. Стога су остали да живе у чергама, најчешће близу румунских и српских села, где су прорицали судбину сујевернима и продавали покућство од гвожђа и дрвета које су сами израђивали. ${ }^{22}$

Темишварска администрација је већ 1718. године упутила управнике дистриката да обаве попис Цигана и да их опорезују са 5 форинти по глави годишње. Касније је ц̧игански харач (Zigeiner Harach) даван у закуп, који је износио најмање 1.200 форинти годишње. 23 У Бечкереку је 1773. године било 54 припадника ромске народности са 16 ожењених глава, сви са српским именима. ${ }^{24}$

Током XVIII столећа у Банат су се досељавали Бугари, Чеси, Словаци, Италијани, Французи и Шпанци. У току рата 1737-1739. године дошло је око 300 бугарских римокатоличких породица. Насељени су делом у Старом Бешенову, а делом у Винги. Из ова два места постепено су се расељавали по Банату. ${ }^{25}$

Италијани су временом почели да побољевају и умиру од маларије, а малобројни преживели асимиловали су се са Немцима. Французи, који су долазили углавном преко монашких редова, такође су веома брзо страдали од маларије. За време управе грофа Мерсија Шпанци су насељени у једном делу Великог Бечкерека, названом Нова Барселона, као врсни вртари, виноградари и занатлије. Уз њихову помоћ требало је урадити канализацију баровитог Баната, добре путеве и мостове. Како нису могли да се прилагоде мочварном и влажном поднебљу, убрзо су доживели судбину Италијана и Француза, а они који су преживели стопили су се са Немцима. ${ }^{26}$

20 Цинцари се у овом попису називају Арнаутима. Видети: Д. Поповић, Срби у Банайу до краја осамнаестиог̄ века, 385-387.

21 М. Митровић, „Јевреји у Банату (1716-1739)”, Зборник за исӣорију Майице срӣске 28 (1983), 37-40, 54.

22 Б. Јанкулов, Прег̄лед колонизачије Војводине, 68-70.

23 Д. Руварац, Ойис Темищварске ейархије 1727. г̄одине, 14.

24 Д. Поповић, Срби у Банаӣуу до краја осамнаесӣог̄ века, 281.

25 Б. Јанкулов, Прегллед колонизаиије Војводине, 58.

26 Исто, 58-59, 62-63. 
Све до седамдесетих година XVIII века у Банату није било мађарских насеља. Марко Ђурковић Сервијски, који је купио посед Турска Кањижа, довео је 1773. године девет мађарских породица на своје имање. То су били први Мађари насељени на територији Темишварског Баната и Темишварске епархије. Нових 47 породица стигло је између 1774. и 1780. године. ${ }^{27}$ Прво мађарско насеље - Сомбор, у Чанадском дистрикту, забележено је у попису из 1774. године. Исте године село Сириг (Серег) из истог дистрикта уписано је као српско-мађарско, што указује на тенденцију досељавања Мађара на територију Темишварске епархије. ${ }^{28}$ Њихов масовнији долазак везан је за укључивање Баната у угарски жупанијски систем, 1779. године, када су на територији Баната, која није била под Војном границом, створене три жупаније: Торонталска, Тамишка и Крашовска. Дворска комора је после тога продала највећи део својих поседа, а главни купци били су Грци, Цинцари и Јермени. Грци и Цинцари су у знатној мери били посрбљени, док су Јермени током времена помађарени. На овакав начин створено племство је поред Срба, и уместо њих, почело да насељава Немце, Мађаре, Словаке, Румуне и друге народе, што је додатно допринело променама у етничкој, али и верској слици целог Баната. ${ }^{29}$

Као последица систематске колонизације Баната, етничка структура насеља на простору Темишварске епархије битно је измењена за нешто више од пола века. Срби и Румуни били су и даље најбројнија етничка скупина појединачно гледано, али је њихов удео у укупном броју становника значајно смањен. Ова појава посебно је погодила равничарски део епархије, насељен почетком века готово искључиво српским становништвом, а касније нарочито изложен бројним таласима колонизације. У сагледавању поменутих демографских кретања уочава се јасна тенденција усложњавања етничких прилика на територији ове епархије, која ће се наставити у наредном столећу.

ORIGINAL SCIENTIFIC PAPER

Ma LJILJANA PUZOVIĆ

National Library of Serbia

Skerlićeva 1, Belgrade, Serbia

ljiljana.puzovic@nb.rs

THE ETHNIC STRUCTURE OF THE POPULATION IN

THE SETTLEMENTS OF THE EPARCHY OF TIMISOARA IN THE MIDDLE OF THE $18^{\mathrm{TH}}$ CENTURY

SUMMARY: The article analyzes the ethnic structure of the settlements on the territory of the Eastern Orthodox Eparchy of Timişoara according to the concriptions of 1743, 1753 and 1774. During the first three decades of the $18^{\text {th }}$ century, only Serbs and Romanians constituted the population of the Eparchy of Timişoara. The Serbs lived mainly in the lowland

${ }^{27}$ Истиорија Новог̄ Кнежевиа и околине, Нови Кнежевац 2003, 245, 543.

28 J. Wolf, Quellen zur Wirtschafts-, Sozial- und Verwaltungsgeschichte des Banats im 18. Jahrhundert, 306-307; J. J. Ерлер, 83-84.

29 Д. Поповић, Срби у Банайу до краја осамнаестиог̄ века, 70. 
regions - Districts of Bečkerek, Pančevo and Čanad. Romanians were the only population in mountainous District of Lugos-Façet. Districts of Timişoara, Čakovo and Lipova were with mixed population. In the meantime, there was an organized colonization of ethnic Germans, into the plains of Banat. Their colonization was carried out in three waves, only the last of which gave more lasting results. There were attempts to settle Bulgarians, Italians and Spaniards, but due to adverse climatic conditions in the Banat swamp, the settlers found it difficult to adapt to this climate, quickly died out, their settlements lasted briefly, and the survivors were gradually assimilated with the Germans. The towns had a more complex ethnic structure than the villages. Greeks, Armenians and Jews lived in towns, mostly as merchants. There was also a group of Romani (Gypsies) living next to Serbian and Romanian villages and paying a special tax to the state. Considering the demographic data, the ethnic situation in the territory of this eparchy gradually became very complex and those trends will continue during the next century.

KEYWORDS: The Metropolitanate of Karlovci, Eastern Orthodox Eparchy of Timişoara, Habsburg Monarchy, Banat of Timişoara, historical demography, ethnic structure, Serbian, Romanian, Germans, $18^{\text {th }}$ century 